\title{
A Family Screening of CD19 Gene Mutation by Restriction Fragment Length Polymorphism
}

\author{
Mehmet Ali Karaselek ${ }^{1}$, Hasan Kapaklı ${ }^{1}$, Sukru Guner ${ }^{1}$, Sevgi Keleş ${ }^{2}$, and Ismail Reisli ${ }^{1}$ \\ ${ }^{1}$ Necmettin Erbakan University Meram Faculty of Medicine \\ ${ }^{2}$ Necmettin Erbakan Universitesi Meram Tip Fakultesi
}

October 31, 2021

\begin{abstract}
Background: CD19 molecule found on B lymphocyte surface forms CD19 complex together with CD21, CD81, CD225 in mature B cells and regulates B lymphocyte activation with antigen stimulation. Mutation(s) in the gene encoding the CD19 molecule affect CD19 protein expression and primary immunodeficiency (PID) occurs. Some genetic method, especially sanger and next generation sequencing and flow cytometric methods are widely used in the diagnosis of PID. The RFLP method, which is faster and cheaper than other mutation detection methods, is rarely used in the diagnosis of PID. The study aimed to genetically identify CD19 deficiency, which is a PID, using the RFLP method. Methods: The study was performed at Necmettin Erbakan University, Meram Medicine Faculty Hospital, Pediatric Allergy and Immunology clinic. A total of 8 patients and two healthy controls could be included in the study. A total of 8 patients and two healthy controls were included in the study, and the relevant region genotypes in the CD19 gene were determined by performing RCR-RFLP analysis. Results: CD19 deficiency was first described by us. The index case, newborn baby and mother were also included in the study. It was determined that the index case (P6) was homozygous mutant, the newborn baby (P7) and mother (P8) had heterozygous genotype. Based on this situation, one child (P1) was found to be homozygous mutant, mother (P2), father (P3) and other children (P4 and P5) had heterozygous genotype in the family, which was determined to be related to the first case. Conclusion: Rapid genetic diagnosis in patients suspected of having a known case of PID insufficiency as a result of clinical and laboratory findings carries a vital risk in terms of treatment options to be offered to patients. Although PCR-RFLP, which is a cheap, safe and fast method, is used to detect known mutations, the use of PID is rare. In our study, it has been shown that it is a method that can be used in the diagnosis of PID by determining genotypes using PCR-RFLP, and especially in terms of rapid genetic testing of family screenings.
\end{abstract}

\section{Hosted file}

CD19 Mutation by RFLP Manuscript.docx available at https://authorea.com/users/443853/ articles/543768-a-family-screening-of-cd19-gene-mutation-by-restriction-fragment-lengthpolymorphism

\section{Hosted file}

Tables and Figures.docx available at https://authorea.com/users/443853/articles/543768-afamily-screening-of-cd19-gene-mutation-by-restriction-fragment-length-polymorphism 